\title{
LA FISONOMÍA DEL FILÓSOFO: RISA Y ANÉCDOTA EN NIETZSCHE
}

\author{
THE PHILOSOPHER'S PHYSIOGNOMY: \\ LAUGHTER AND ANECDOTE IN NIETZSCHE
}

\section{MARCELA RIVERA HUTINEL*}

\section{RESUMEN}

El presente trabajo procura dilucidar el modo en que el "proyecto" nietzscheano concede a la risa y a la anécdota un lugar preeminente en su pensamiento, actuando así a contrapelo de una tradición filosófica que ha tendido a situarlas en el exterior de su propio ejercicio. La risa y la anécdota convergen, en Nietzsche, como potencias dislocadoras de la filiación ascética y del temple de seriedad que han definido hasta ahora la grave fisonomía del filósofo. Por medio de una transfiguración de este pathos, la filosofía es llamada, con este pensador, a ganar la liviandad de la ciencia jovial.

Palabras clave: Nietzsche, anécdota, risa, ciencia jovial, genealogía, ideal ascético.

\section{ABSTRACT}

The purpose of this essay is to elucidate the way in which the Nietzschean "project" gives laughter and anecdote a preeminent place in its thinking, thus acting against a philosophical tradition that has tended to locate them outside its own exercise. Laughter and anecdote converge, in Nietzsche, as dislocating powers of the ascetic filiation and the temperament of seriousness that have so far defined the grave philosopher's physiognomy. By means of a transfiguration of this pathos, the philosophy is called, through this thinker, to gain the levity of the gay science.

Keywords: Nietzsche, anecdote, laughter, gay science, genealogy, ascetic ideal.

Recibido: 28.03.14. Aceptado: 03.11.15.

* Licenciada en Psicología y Filosofía. Estudiante del Doctorado en Filosofía mención Estética y Teoría del Arte. Profesora asociada del Departamento de Filosofía de la Universidad Metropolitana de Ciencias de la Educación, Santiago, Chile. Correo electrónico: mriverahutinel@ gmail.com 
Tomar en serio. En la mayoría de los hombres el intelecto es una máquina pesada, sombría, rechinante, que cuesta poner en movimiento: cuando quieren trabajar y pensar bien con esta máquina, lo llaman "tomar en serio el asunto” - ¡oh, cuán fastidioso tiene que serles el pensar-bien! Tal como parece, la amada bestia hombre pierde el buen humor cada vez que piensa bien: ¡se pone "serio"! Y "en donde hay risa y jovialidad nada vale allí el pensar" -así suena el prejuicio de esta bestia seria en contra de toda "ciencia jovial”.- ¡Pues bien! ¡Mostremos que es un prejuicio! (Nietzsche, 1999, p. 188).

Digo que debemos reír a la vez que buscar la verdad [...] (Epicuro, 2012, p. 102).

Lo que puede ser: reír. Sobre todo no ironizar, ni burlarse, sino reír, el cuerpo sacudido de pensamiento no posible (Nancy, 2000, p. 95).
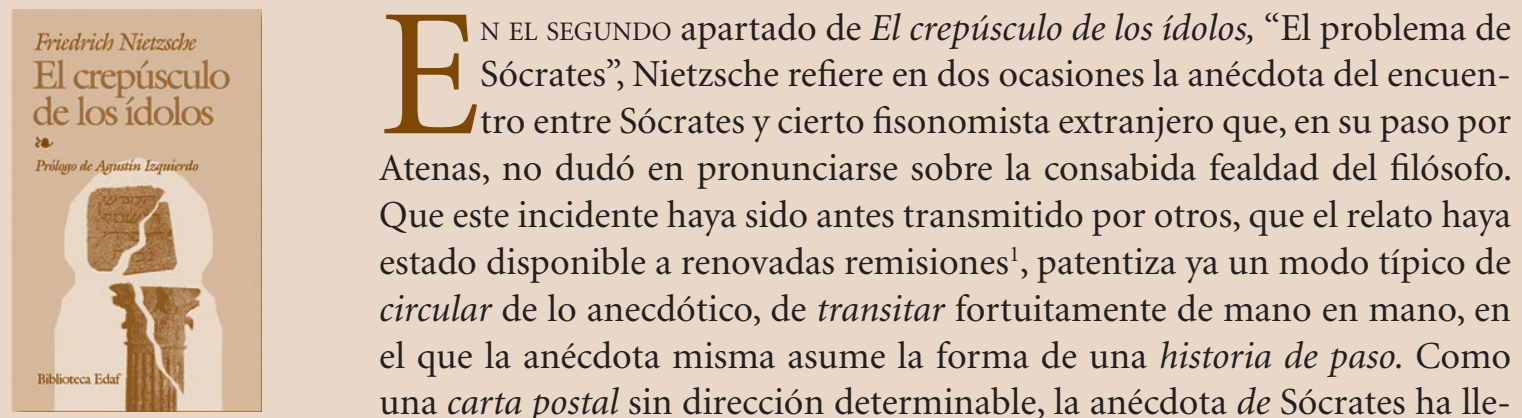
Atenas, no dudó en pronunciarse sobre la consabida fealdad del filósofo. Que este incidente haya sido antes transmitido por otros, que el relato haya estado disponible a renovadas remisiones ${ }^{1}$, patentiza ya un modo típico de circular de lo anecdótico, de transitar fortuitamente de mano en mano, en el que la anécdota misma asume la forma de una historia de paso. Como una carta postal sin dirección determinable, la anécdota de Sócrates ha llegado, entonces, hasta Nietzsche ${ }^{2}$ :

\footnotetext{
${ }^{1}$ El suceso, según consta en las Disputaciones Tusculanas de Cicerón, es el que sigue: "Cuando, en una reunión, Zópiro, que afirmaba que podía discernir la naturaleza de cada persona por su apariencia externa, llegó a la conclusión de que en Sócrates había muchos vicios, se convirtió en el hazmerreír de los demás, que no reconocían en Sócrates esos vicios, pero el mismo Sócrates le consoló al decir que esos vicios le eran connaturales, pero los había erradicado con la ayuda de la razón” (2005, p. 383).

${ }^{2}$ Intentaremos esclarecer mínimamente este carácter transitivo, de paso, que hemos atribuido a la anécdota. 1) Decimos de ella que es una historia de paso, teniendo presente el estatuto singular de lo que en ella se narra. Pues lo que difunde la anécdota no es una gran gesta inscrita en la memoria de los monumentos de la Historia mayúscula, sino una pequeña historia, marginal o insignificante desde la óptica de esa historia monumental. Se trata, más bien, de la puesta en circulación, de la publicidad de cierto evento de orden privado, "sería ella -escribe Oyarzún- lo que circula públicamente como privado, como perteneciente a la esfera de lo privado" (1996, p. 39). Lo que se cuenta en la anécdota es un suceso en la vida de alguno, cuyo nombre propio se ofrece como la verdadera signatura del relato (hablamos de las anécdotas de Sócrates de Diógenes, etc.). Haciendo ostensible una experiencia singular de un individuo en particular, se nos dice como éste, en medio de las cosas del mundo, tropieza con algo que lo obliga a poner en evidencia su propia idiosincrasia; 2) A la singularidad de lo narrado, se añade la brevedad de la anécdota. La eficacia del relato, su función impresionante, directamente ligada a su memorabilidad, parece depender de esta concisión. De modo que, si bien la anécdota es un relato, en ella se comprime o se condensa
} 
Un extranjero que entendía de rostros, pasando por Atenas, le dijo a Sócrates a la cara que era un monstrum -que escondía en su interior todos los vicios y apetitos malos. Y Sócrates se limitó a responder: “¡Usted me conoce, señor mío!"- (1994b, p. 39).

Cuando aquel fisonomista le hubo desvelado a Sócrates quién era él, una madriguera de todos los apetitos malos, el gran irónico pronunció todavía una frase que da la clave para comprenderlo. "Es verdad, dijo, pero he llegado a ser dueño de todos” (1994b, p. 42).

Habrá que desentrañar, sin duda, qué hace esta historia entre sus manos, sobre todo si se tiene en cuenta que éstas son las manos de un filósofo. Pues Nietzsche, como argüiremos luego, ha abordado filosóficamente la anécdota como lugar del pensamiento, y al hacerlo, ha actuado a contrapelo de una "memoria filosófica" configurada a partir de la obliteración de lo anecdótico. Por ello, antes de aclarar qué detuvo a Nietzsche en esta anécdota sobre la excéntrica fisonomía de Sócrates, y en qué medida su pensamiento tropieza allí con algo que lo fuerza, que lo hace pensar, intentaremos dilucidar hasta qué punto el juicio que sanciona el estatuto de la anécdota como exterior a la filosofía se liga esencialmente a la conceptualización filosófica de la tradición y a la autorrepresentación que la filosofía se hace de su eminente relación con la verdad. A través de esta indagación, procuramos comprender de qué modo el "proyecto" nietzscheano se perfila propiamente como una suerte de transfiguración de la filosofía, que conlleva a su vez una dislocación de la grave fisonomía que va unida a ese nombre 3 . Y cómo

al máximo la sucesión narrativa. Su distensión es la de una escena que no requiere de otras para completarse. O bien, como precisa Oyarzún en su libro sobre Diógenes y la anécdota en filosofía: "Ninguna anécdota pertenece a una continuidad (sucesión) narrativa, sino que se presenta, por así decir, cerrada sobre sí misma. La anécdota tiene carácter monádico, si cabe expresarse de ese modo [...] Debe la anécdota bastarse a sí misma, no requerir, en general de antecedentes" (1996, p. 167); 3) Se ha considerado plausible establecer un nexo entre el modo de circular de lo anecdótico y la estructura postal, tal y como ésta ha sido pensada por Jacques Derrida (2001). Pertenece a la estructura de la anécdota que ésta no se brinde jamás en el presente; su presencia está de antemano diferida por el momento insuprimible de su inscripción. De ahí que sea imposible interrumpir su tránsito fortuito, de mano en mano, sin destinatario conocido; difiriendo de sí, ella está hecha para pasar (“Tele -sin telos” [2001, p. 363], escribe Derrida, a propósito de esta estructura destinerrante del relevo postal).

${ }^{3}$ Sobre la filosofía como arte de la transfiguración, Cf. Nietzsche, 1999, prólogo, \$3. Deleuze, por su parte, aborda esta transfiguración nietzscheana del pathos de la filosofía, a partir del carácter antidialéctico de la filosofía de Nietzsche: "El pluralismo tiene a veces apariencias dialécticas; pero es su enemigo más encarnizado, su enemigo profundo. Por ello debemos tomar en serio el carácter resueltamente antidialéctico de la filosofía de Nietzsche [...] Al elemento especulativo de la negación, de la oposición o de la contradicción, Nietzsche opone el elemento práctico de la 
quizás, con esto, la filosofía es llamada a ganar lo más difícil: la liviandad de la ciencia jovial.

Que el juicio filosófico sancione la exterioridad de la anécdota a la filosofía, contraponiendo el estatuto accidental, accesorio e insignificante de lo anecdótico a la dignidad de su tarea, habla ya de la correspondencia entre filosofía y seriedad. Dicho temple de seriedad, que la filosofía asume como una especie de aval que legitima la valía de su propio quehacer, como una suerte de "hipoteca de sus criterios", constituye uno de los puntos de litigio más agudos que Nietzsche tiene ante la vista. Así, "tras haber dedicado suficiente tiempo a leer a los filósofos entre líneas y a mirarles las manos" (1994a, p. 23), luego de observarlos largamente "con una mirada a medias desconfiada y a medias sarcástica", Nietzsche sospecha de ese "ruido grande y virtuoso" que todos ellos levantan "tan pronto como se toca, aunque sólo sea de lejos, el problema de la veracidad” (1994a, p. 25). El pathos de la seriedad se revela así tramado al valor de la verdad, y más precisamente, a la solidificación, a la monumentalización de dicho valor. Ese "ruido grande y virtuoso", antes que una evidencia de rigor, parece más bien un ardid que procura mantener a distancia, o inhibir, toda interrogación acerca de la ver$\mathrm{dad}^{5}$. Desde esta perspectiva, se explica por qué la tenaz apuesta genealógica de Nietzsche, tendiente a "recorrer con preguntas totalmente nuevas y, por así decirlo, con nuevos ojos, el inmenso, lejano y tan recóndito país de la moral" (Nietzsche, 2006, p. 29), decide poner en evidencia la comprometedora filiación entre filosofía e ideal ascético (lazo que hasta ahora ha hecho de la seriedad el pathos de la filosofía); y por qué, entonces, es factible leer en el prólogo de La genealogía de la moral una incitación a conquistar la liviandad del gai saber por medio de la crítica de los valores morales:

diferencia: objeto de afirmación y de placer. [...] "El placer de sentirse diferente" [BM, 260]: éste es el nuevo elemento conceptual, agresivo y aéreo, que el empirismo opone a las pesadas nociones de la dialéctica y, sobre todo, como dice el dialéctico, al trabajo de lo negativo. Que la dialéctica sea un trabajo y el empirismo un placer, ya es caracterizarlos suficientemente. Y, ¿Quién se atreve a decir que hay más pensamiento en un trabajo que en un placer? [...] El "sí" de Nietzsche se opone al "no" dialéctico; la afirmación a la negación dialéctica; la diferencia a la contradicción dialéctica; la alegría, el placer, al trabajo dialéctico; la ligereza, la danza, a la pesadez dialéctica; la hermosa irresponsabilidad a las responsabilidades dialécticas" (Deleuze, 2002, pp. 17-18).

${ }^{4} \mathrm{La}$ fórmula aparece en el contexto de un análisis sobre el poder emancipatorio de la risa en el cinismo antiguo: "Que la memoria filosófica prefiera conservar como única cosa digna la oculta seriedad y deseche la broma, la inventiva, la risa franca y la obscenidad como perversión y extravagancia rutilantes habla sobre todo de ella misma, de lo que podríamos llamar una cierta hipoteca de sus criterios (de unos que en todo caso prefieren soslayar la otra historia que pasa por lo bajo en esos temibles juegos)". Cf. Oyarzún, 1996, p. 132.

${ }^{5}$ Cf., Birnbaum, 2004, p. 99: “[...] Lo serio del conocimiento parece una declaración de servilismo antes que un testimonio de rigor". 
me parece que no hay ninguna cosa que compense tanto tomarla en serio; de esa compensación forma parte, por ejemplo, el que alguna vez se nos permita tomarla con jovialidad. Pues, en efecto, la jovialidad, o, para decirlo en mi lenguaje, la gaya ciencia -es una recompensa: la recompensa de una seriedad prolongada, valiente, laboriosa y subterránea, que, desde luego, no es cosa de cualquiera (Nietzsche, 2006, pp. 29-30).

En concordancia con la búsqueda de una filosofía transfigurada por la afirmación de su derecho a reír, en el tercer tratado de La genealogía de la moral Nietzsche hace explícita la exigencia de interpretar la conexión entre la "voluntad de verdad" y la flagelante renuncia ascética del mundo sensible. Intentando tornar legible lo que a la filosofía le va en ese lazo, se pregunta “¿Qué significa que un filósofo rinda homenaje al ideal ascético?”:

Es indiscutible que, desde que hay filósofos en la tierra, y en todos los lugares en que los ha habido [...], existen una auténtica irritación y un auténtico rencor de aquellos contra la sensualidad [...]; igualmente existen una auténtica parcialidad y una auténtica predilección de los filósofos por el ideal ascético en su totalidad [...] Ambas cosas forman parte del tipo [Typus], como hemos dicho; y si ambas faltan en un filósofo, entonces éste no pasa de ser -estése seguro de ello- un filósofo "por así decirlo". ¿Qué significa esto? Pues hay que empezar por interpretar tal hecho: en sí está ahí tontamente por toda la eternidad, como toda "cosa en sî" (2006, pp. 138-139).

En un cierto sentido, escribe Nietzsche, la cuestión parece estar zanjada desde la invención de la filosofía. Desde que hay filósofos en la tierra, una filiación ascética define la tipología de la "la bête philosophe", aquella voluntad que aspira a la verdad. Hasta ahora, en efecto, la fisonomía del filósofo parece amalgamarse incontestablemente con la del sacerdote ascético:

¿Me pregunta usted qué cosas son idiosincrasia en los filósofos? [...] Ellos creen otorgar un honor a una cosa cuando la deshistorizan, sub especie aeterni [desde la perspectiva de lo eterno], -cuando hacen de ella una momia [...] ¡Ser filósofo, ser momia, representar el monótono-teísmo con una mímica de sepulturero! -iY, sobre todo, fuera el cuerpo, esa lamentable idée fixe [idea fija] de los sentidos! [...] (Nietzsche, 1994b, pp. 45-46).

Y, sin embargo, de acuerdo a la indicación dada por Nietzsche en La genealogía de la moral, habrá que actuar a contracorriente de esta presuposición "monótono-teísta" de la filosofía (que anhela un mundo que no se con- 
tradiga, que no falsee, que no cambie), interpretando el hecho -hasta ahora "eternizado", incuestionado- de su filiación ascética. Es preciso interrogar genealógicamente aquello que, en esta común recusación de la dimensión contingente del mundo que aúna al filósofo y al asceta, pasa por no tener historia ${ }^{6}$. El genealogista, de este modo, presta oídos a las "condiciones y circunstancias" que, en el surgimiento de la filosofía, dieron lugar a esta connivencia entre saber y moral. $\mathrm{Y}$ al hacerlo, constata en primer lugar la ceguera de la filosofía respecto de su propio devenir. Pues allí donde la filosofía ha pensado su historia como historia de la verdad (ya se la piense como el devenir dialéctico de la verdad misma, o bien como un errar en su búsqueda, pero siempre desde la verdad, en orden a ella), jamás se ha preguntado cómo llegó a ser posible una voluntad que quiere la verdad: ¿ de dónde procede su aspiración a la verdad? ¿Qué tipo de voluntad, históricamente cimentada, ha llegado, alguna vez, a creer en la verdad? ¿Quién busca lo verdadero? ${ }^{7}$ Escuchando la historia, el genealogista obliga a repensar las condiciones y los elementos con que la filosofía se ha interpretado a sí misma. Esta zona en penumbra, desatendida por toda filosofía dogmática, es la que surge desde el fondo problemático reactivado por la pregunta genealógica. En efecto, la pregunta de Nietzsche "¿qué significa el ideal ascético en un filósofo?" apunta a esclarecer la extraña anfibología de una voluntad que se ha emplazado en el doble terreno de la filosofía y la moral, revelando por esta vía una deuda posibilitadora que hasta ahora se mantenía impensada. Pues, de acuerdo a la evaluación nietzscheana, la filosofía, en su momento constituyente, sólo pudo establecerse al amparo de un pathos específico, el

\footnotetext{
${ }_{6}$ ¿Si el genealogista se ocupa de escuchar la historia más que de alimentar la fe en la metafísi$\mathrm{ca}$, qué es lo que aprende? Que detrás de las cosas existe algo muy distinto: en absoluto su secreto esencial y sin fechas, sino el secreto de que ellas están sin esencia, o que su esencia fue construida pieza por pieza [...] El sentido histórico, y es en esto en lo que practica la "wirkliche Historie" [la Historia real o efectiva], reintroduce en el devenir todo aquello que se había creído inmortal en el hombre". Cf., asimismo, Nietzsche, 2007, p. 44: "El pecado original de todos los filósofos es la falta de sentido histórico; no pocos toman incluso la configuración más reciente del hombre, tal como ha surgido bajo la impronta de determinadas religiones, aun de determinados acontecimientos políticos, como la forma fija de la que debe partirse. No quieren enterarse de que el hombre ha devenido". Cf., Foucault, 2000, pp. 105, 116.

${ }^{7}$ La filosofía tradicional, como apunta Deleuze a este respecto, omite por definición esta pregunta por la voluntad específica en la que arraiga la aspiración a la verdad: “[...] los filósofos pretenden que el pensamiento, en tanto que pensamiento, busca la verdad, que ama "por derecho" la verdad, que quiere "por derecho" la verdad. Al establecer una relación de derecho entre pensamiento y verdad, al relacionar así la voluntad de un pensador puro a la verdad, la filosofía evita relacionar la verdad con una voluntad concreta que sería la suya, con un tipo de fuerzas, con una cualidad de la voluntad de poder" (Deleuze, 2002, p. 135).
} 
de la valoración ascética del mundo; el filósofo, para afirmar su existencia, tuvo que tomar en préstamo esta máscara:

[... al principio el espíritu filosófico tuvo siempre que disfrazarse y enmascararse en los tipos antes señalados del hombre contemplativo, disfrazarse de sacerdote, mago, adivino, de hombre religioso en todo caso, para ser siquiera posible en cierta medida: el ideal ascético le ha servido durante mucho tiempo al filósofo como forma de presentación, como presupuesto de existencia -tuvo que representar ese ideal para poder ser filósofo, tuvo que creer en él para poder representarlo. La actitud apartada de los filósofos, actitud peculiarmente negadora del mundo, hostil a la vida, incrédula con respecto a los sentidos, desensualizada, que ha sido mantenida hasta la época más reciente y que por ello casi ha valido como la actitud filosófica en sí, esa actitud es sobre todo una consecuencia de la precariedad de las condiciones en que la filosofía nació y existió en general: pues, en efecto, durante un período larguísimo de tiempo la filosofía no hubiera sido en absoluto posible en la tierra sin una cobertura y un disfraz ascético, sin una autotergiversación ascética. Dicho de manera palpable y manifiesta: el sacerdote ascético ha constituido, hasta la época más reciente, la repugnante y sombría forma larvaria, única bajo la cual le fue permitido a la filosofía vivir y andar rondando de un lado para otro (Nietzsche, 2006, p. 150).

La moral ascética es descrita, en este pasaje, como un primario atavío del filósofo sin el cual éste no hubiese tenido ninguna posibilidad de supervivencia. Escribe Deleuze al respecto: "Debemos pensar en la filosofía como en una fuerza. Ahora bien, la ley de las fuerzas es que ellas no pueden aparecer sin cubrirse con la máscara de las fuerzas preexistentes. [...] Ha sido necesario que el filósofo adoptara las maneras de las fuerzas precedentes, que tomara la máscara del sacerdote" $(2000, \text { p. } 25)^{8}$. Nietzsche busca sopesar el sentido de la apropiación de esta máscara por parte del filósofo. Éste ha debido, para afirmar $s u$ existencia, sacar provecho de esta forma larvaria, ha debido crecer (y creer) en ella, disimularse y estabilizarse bajo su cobijo. No obstante, aún es preciso interrogar la serie de compromisos en que se ve envuelta la actividad filosófica a partir de esta operación de investidura y camuflaje. La pregunta que cabe plantear es si, en efecto, se ha transformado realmente la $f a z$ del filósofo o si, en su defecto, aquello que fue un necesario atavío se ha anquilosado en una especie de luctuoso atavismo; ¿el filósofo ha salido ya del envoltorio ascético que lo abrigaba?:

${ }^{8}$ Cf., asimismo, Deleuze, 2002, Capítulo I, 2. 
¿Se ha modificado realmente esto? Ese policromo y peligroso insecto, ese "espíritu" que aquella larva encerraba dentro de sí, ¿ha terminado por quedar realmente liberado de su envoltorio y ha podido salir a la luz, gracias a un mundo más soleado, más cálido, más luminoso? ¿Existe ya hoy suficiente orgullo, osadía, valentía, seguridad en sí mismo, voluntad de espíritu, voluntad de responsabilidad, libertad de la voluntad, como para que en adelante "el filósofo" sea realmente -posible en la tierra? (Nietzsche, 2006, p. 150).

Por cierto, todo hace sospechar que sobre la fisonomía del filósofo se graban aún los rastros de esa forma larvaria, dada su creencia en la seriedad como pathos irrenunciable del pensamiento: "Pensar' y 'tomar en serio', 'tomar con gravedad una cosa' -en ellos [los filósofos] esto va junto: únicamente así lo han 'vivido’ ellos” (Nietzsche, 1994a, p. 158). La filosofía ha pontificado su propia seriedad, ha creído firmemente en ella, la ha petrificado como su temple constitutivo. Ahora bien, ¿no cabe barruntar, como lo hace Nietzsche, que la prohibición de reír, que la identificación del pensamiento con lo serio, no es más que un resabio de esa matriz ascética en la que se incubó el filósofo? ¿Y que, por ende, la seriedad no es más que un prejuicio, el presupuesto de una "voluntad de verdad" encorsetada en el envoltorio de su "máscara de sacerdote" e incapaz por eso mismo de "recorrer con nuevos ojos" la escena de su propia gestación? De ahí que, insistimos sobre esto, cobre sentido la invitación a la ciencia jovial presente en el prólogo de La genealogía de la moral, como una incitación a dislocar el límite ascético-moral de la actividad filosófica, límite que la filosofía veneradora de la verdad no ha estado aún en condiciones de atestiguar. La eclosión de este límite moral está fuera de las posibilidades de la filosofía tradicional, toda vez que ésta mantiene una relación supersticiosa, cultual, con el valor de la verdad ("La 'voluntad de verdad' [.... , esa famosa veracidad de la que todos los filósofos han hablado hasta ahora con veneración..." [Nietzsche, 1994a, p. 21] $)^{9}$. Es por ello, precisa el genealogista definiendo su tarea, que la 'voluntad de verdad' necesita una crítica que ponga en duda esta destinación a la verdad, que ponga en entredicho el valor mismo de verdad ${ }^{10}$. Y dado que toda verdad venerada tiene por salvaguarda esta misma investidu-

\footnotetext{
${ }^{9}$ El subrayado es nuestro. Cf., Deleuze, 2002, p. 139: "La voluntad de verdad pertenece aún al ideal ascético, la forma es siempre cristiana".

10 "La voluntad de verdad necesita una crítica -con esto definimos nuestra propia tarea-, el valor de la verdad debe ser puesto en entredicho alguna vez, por vía experimental [...]" (Nietzsche, 2006, p. 193).
} 
ra, que la mantiene a salvo, indemne del riesgo de su puesta en discusión ${ }^{11}$, dicha crítica, consecuentemente, sólo puede provenir de una voluntad filosófica transfigurada, que ya no necesite postrarse ante ningún absoluto, es decir, que pueda reír ante él enseñándole dos signos de interrogación ${ }^{12}$, una nueva voluntad, cuyas "fuerzas vivas e impulsoras" precisen salir del envoltorio moral que limitaba su capacidad de hacer preguntas:

A favor de la crítica. Algo te aparece hoy como un error, y que antes amaste como una verdad o como una probabilidad: lo rechazas y presumes que tu razón ha ganado allí una victoria. Pero tal vez aquel error de entonces, cuando tú aún eras otro -siempre eres otro-, te era tan necesario como todas tus actuales "verdades", por decirlo así, como una piel que te disimulaba y te embozaba mucho que aún no te estaba permitido ver (el énfasis es nuestro). Tu nueva vida, no tu razón, mató para ti aquella opinión: ya no la necesitas más, y ahora se desmorona sobre sí misma, y la sinrazón sale de ella arrastrándose como un gusano hacia la luz. Cuando ejercemos la crítica no es nada arbitrario e impersonal -es, por lo menos muy a menudo, la prueba de que en nosotros hay alli fuerzas vivas e impulsoras que expulsan una corteza (el énfasis es nuestro). Negamos y tenemos que negar, porque algo quiere vivir y afirmarse en nosotros, ¡algo que nosotros tal vez no conocemos aún, no vemos aún!-. Esto sea dicho a favor de la crítica (Nietzsche, 1999, p. 179).

Se desprende de este pasaje que, en Nietzsche, no se trata de que "la" filosofía quede devastada por esta puesta en evidencia de sus límites mora-

\footnotetext{
${ }^{11}$ Cf., Zúñiga, 2003, pp. 88-89: “Así pues, algo del temple de la “seriedad” está enunciado en la noción de "verdad" y en la totalización inteligible de lo real que ella involucra y pesquisa [...] Más aún: la seriedad hace mella, en un momento específico (en este momento de trasluz del nihilismo, para ser más enfáticos) sobre la propia filosofía entendida a la usanza tradicional, en la medida en que impone férreas restricciones al ansia interrogadora y ferozmente dubitativa. La seriedad limita. La filosofía, inserta en la direccionalidad que pueda proveerle su circunspección constitutiva, se ve igualmente limitada -por ejemplo, no preguntaba acerca de la propia verdad, no ponía en duda el valor de los valores. Es por eso que la filosofía debe transfigurarse, autosuperarse: percatarse de su propia seriedad veneradora, aprender a desconfiar de sí misma [...]”.

${ }^{12}$ En Nietzsche, el derecho a reír, la no-restricción de la comicidad, se vincula estrechamente con el poder emancipatorio de la pregunta. Si la seriedad coarta el diligente afán de la sospecha, señalándole que ya no hay nada más que preguntar, que hay algo que ya no se puede poner en duda (la seriedad como consagración de la verdad), la risa en cambio siempre está dispuesta a desestabilizar el valor apuntalado por la veneración. El "genuino signo de interrogación" (Nietzsche, 1999 , p. 254) no tiene límites porque siempre está acompañado por la jovialidad, que se permite no creer en nada porque puede reír ante todo; se trata -en primer lugar- de una voluntad siempre dispuesta a exponerse a la dislocación de su propia perspectiva. Sobre la prohibición de reír ante los valores decretados inmutables, CF., Nietzsche, 1999: Libro I, \$1. Cf., también, Libro quinto, \$375: "Por qué parecemos epicúreos": “[... inclinación casi epicúrea del conocimiento, que no quiere dejar escapar con facilidad el carácter de signo de interrogación de las cosas”.
} 
les; más bien, lo que la crítica conlleva es la afirmación de aquellas fuerzas activas y expansivas que permiten franquear las restricciones impuestas por la corteza veneradora a la potencia del pensamiento. La crítica expresa, por tanto, "nuevas fuerzas capaces de dar otro sentido al pensamiento" (Deleuze, 2002, p. 142). Este pensamiento transfigurado ya no necesita subordinar la existencia al orden de la verdad, ya no requiere más desoír la vida, a diferencia de una filosofía que, por su misma necesidad de certidumbre, debe desestimar la existencia para poder satisfacer su anhelo de un fundamento inconmovible ${ }^{13}$ :

[Los filósofos pensaban] que los sentidos los tentaban a alejarse de $s u$ mundo, el frío reino de las "ideas", hacia una peligrosa isla del sur: donde, como temían, sus virtudes filosóficas se derretirían como la nieve bajo el sol. En ese entonces la "cera en los oídos" era casi condición del filosofar; un filósofo genuino ya no escuchaba más la vida (Nietzsche, 1999, p. 243).

No escuchar la vida ha sido el signo distintivo de un pensamiento constreñido en los límites de una vida reactiva. A partir de los residuos siempre operantes del ascetismo, los filósofos han juzgado que la vida no es lo que debería ser, ya que su carácter heteróclito, inanticipable, disperso, no coincide con el estatuto supuestamente inamovible de lo verdadero; es preciso, entonces, corregir este carácter insurrecto de la vida, rectificar -en orden a la razón- la "aparente sin razón" de las cosas:

Semejante funcionamiento del conocimiento violenta lo frívolo, lo superfluo, lo accesorio. Conocer exige suprimir toda extravagancia, grano de arena perturbador en la lógica implacable del conocimiento [...] El exceso de la vida sobre cualquier apropiación debe ser desterrado porque pone en peligro a la regla: su "además" es decididamente un "de más" (Birnbaum, 2004, p. 98).

La búsqueda de un fundamento inmutable, por ende, se revela sintomática de una voluntad que no soporta la falta de estabilidad, que pretende

\footnotetext{
${ }^{13}$ La crítica genealógica, que aboga por la continua dislocación de las pretensiones totalizadoras de la voluntad de verdad, pone en evidencia que la separación entre el conocimiento y la vida es una oposición de origen moral; tras el postulado de un orden trascendente (y su correlativa recusación de la dimensión contingente del mundo) no hay otro basamento más que aquel: "La creencia en un orden exterior al mundo es una creencia en el sentido plenamente moral del término y no un simple postulado" (Birnbaum, 2004, p. 25).
} 
dominar el exceso de la vida sometiéndolo al conocimiento, a la totalización inteligible de lo real, puesto que la "idea" amortiza su desasosiego:

Y nosotros los filósofos ¿hemos entendido por conocimiento, en rigor, algo más? Lo consabido [Das Bekannte], eso quiere decir: aquello a lo que estamos habituados, de tal manera que ya no nos sorprendemos más ante ello $[\ldots]$ ¿No es nuestro hacer menester del conocer, precisamente, esa menesterosidad por lo consabido, la voluntad de descubrir bajo todo lo extraño, inhabitual, cuestionable, algo que no nos intranquilice más? ¿No será el instinto de temor el que nos manda a conocer? ¿No será el júbilo de los que conocen, justamente el júbilo del sentimiento de seguridad nuevamente recuperado? (Nietzsche, 1999, p. 220).

Contraponiéndose a esta tipología de la voluntad que recela de la vida, que tapona sus oídos para no oír lo que en la vida escapa a la razón, la filosofía transfigurada afirma un pensamiento capaz de llevar la vida hasta el extremo de lo que ella puede, un pensamiento que afirma la vida, en lugar de un conocimiento que se opone a ella. Tras este conocimiento que reduce el mundo a la idea, que mide y limita la vida, que se muestra impelido por el temor ante la inquietud que moviliza la existencia, podría alojarse un principio contrario a la vida misma. Nietzsche presiente que entre la "voluntad de verdad" y la "voluntad de muerte", existe un vínculo estrecho: "La voluntad de verdad' -eso podría ser una oculta voluntad de muerte" (1999, p. 206). Quisiéramos retener esta afirmación nietzscheana -que evidencia el compromiso entre la pretensión monolítica de la voluntad de verdad y la "máscara mortuoria" que la acompaña- para retomar nuestra pregunta inicial: hasta qué punto esta plataforma moral de la filosofía tradicional se vincula con el motivo de la depreciación de lo anecdótico. Esta desvalorización de la anécdota (y por ende, de lo que acaece en la vida de uno que está siempre expuesto a los otros) ¿no sería acaso un indicio inmediato del vínculo esencial que, a partir del platonismo, se ha establecido entre filosofía y muerte (en tanto que éste exige que el conocimiento se cumpla en una esfera desligada de la vida)? ${ }^{14} \mathrm{~A}$ fin de esclarecer dicho nexo, recurriremos

${ }^{14}$ Este nexo se muestra ejemplarmente en el Fedón de Platón: “[...] los que se ha purificado suficientemente en el ejercicio de la filosofía viven completamente sin cuerpos para todo el porvenir" (1988a, p. 135; el énfasis es nuestro). En sentido platónico, la vida misma y el saber de la vida se fundarían en la muerte. La muerte es el borde ascético que, purgando el cuerpo, posibilita el acceso al orden inmutable de la esencia. Es en orden a la verdad, con vistas a ella, que el cuerpo del filósofo ha de ser sacrificado. 
a la lectura de una de las más afamadas anécdotas de la filosofía, ya que ella porta el privilegio de ser considerada la primera de su historia. En ella se cuenta que, en el borde de un pozo de Mileto, el primer filósofo perdió el suelo bajo sus pies.

Sóc.- Es lo mismo que se cuenta de Tales, Teodoro. Éste, cuando estudiaba los astros, se cayó en un pozo, al mirar hacia arriba, y se dice que una sirvienta tracia, ingeniosa y simpática, se burlaba de él, porque quería saber las cosas del cielo, pero se olvidaba de las que tenía delante y a sus pies. La misma burla podría hacerse de todos los que dedican su vida a la filosofía (Platón, 1988b, p. 240).

Así, en la orilla de ese pozo de Mileto, según consigna el relato que el Sócrates de Platón hace en el Teeteto, habría acontecido la primera anécdota de la filosofía, el primer bosquejo anecdótico de la figura del filósofo. En la versión de Platón (pues, como es sabido, Diógenes Laercio también recoge el incidente de la caída, pero en su recensión de la anécdota Tales tiene por testigo del traspié a una vieja mujer que le acompaña ${ }^{15}$ ), el episodio se completa con la súbita irrupción de la risa de una joven esclava tracia que presencia el accidente. En este bosquejo anecdótico se plasma la imagen que del filósofo y de su rareza se hace el espectador común, al mismo tiempo que se anuncia (en el suplemento moral que Platón -o mejor dicho, el platonismo- añade a la historia: "la misma burla podría hacerse a todos los que dedican su vida a la filosofía") la crítica que la propia filosofía ejerce sobre dicha opinión, impugnando la perspectiva de la dóxa para juzgar propiamente sobre la dignidad de su caso. La filosofía vindica de este modo la diferencia de su propio saber, de su propio proyecto de saber, con respecto a lo que ella misma define como su exterioridad. Esta "anécdota filosófica", en consecuencia, trazaría el límite que separa a la filosofía de su otro: ella misma sería la puesta en escena de una decisiva confrontación entre la filosofía y su afuera ${ }^{16}$.

\footnotetext{
${ }^{15}$ Para la versión de la anécdota en Diógenes Laercio, Cf., Vidas (2007, p. 49): “Se dice que salía de su casa acompañado por una vieja para contemplar las estrellas y cayó en un pozo. Cuando se lamentaba, la vieja dijo: 'Y tú, Tales, que no puedes ver lo que tienes ante tus pies, ¿crees que vas a conocer las cosas del cielo?'”.

${ }^{16}$ Ahora bien, si consideramos -como lo advierte Pablo Oyarzún en El dedo de Diógenes-, que "la crítica que la filosofía hace de la dóxa [...] implica ya una sanción acerca del estatuto de la anécdota en filosofía, una sanción que define a ese estatuto como exterior a la filosofía misma", si por ende, "la anécdota es la exterioridad de la filosofía, [...] aquello que concierne a la filosofía misma como su propia exterioridad" (1996, p. 44), queda por interrogar la extraña índole (a la vez interior y exterior) de una "anécdota de la filosofía" que sanciona el carácter extrínseco de
} 
Cuando Platón introduce la anécdota del tropiezo y, con ésta, la risa de la muchacha tracia, parece hacer de la risa y de la anécdota el ominoso reverso del único lugar donde la verdad acontece y al que debe plegarse aquel que desea el conocimiento: el orden trascendente, el mundo eterno. Pues, mientras el filósofo, tal y como describe en el Teeteto, parece ir cayendo de pozo en pozo en la plaza pública ("cuando una persona así en sus relaciones particulares o públicas con los demás se ve obligada a hablar, en el tribunal o en cualquier otra parte, de las cosas que tiene a sus pies y delante de los ojos, da que reír no sólo a las tracias, sino al resto del pueblo" [Platón, 1988b, p. 241]), el mundo de las ideas se emplaza ante él como el firme basamento de lo Mismo. En esta restitución del suelo firme, Platón, por mediación de Sócrates, hace del conocimiento de lo verdadero aquello que anula la caída, obturando las múltiples brechas que se abren en la marcha de la polis: el saber de la verdad, en tanto no depende de la experiencia ni de la confrontación con los otros, redime al filósofo de caer en los pozos inevitablemente esparcidos en su tránsito por la vida en común. El conocimiento de la Idea, sojuzgando la fuerza de lo accidental, absolvería al teórico del extravío del mundo, del tropiezo con las cosas y seres singulares. Como subraya Birnbaum:

la "anécdota en la filosofía". Podemos presentir a qué se expone el discurso filosófico cuando, valiéndose él mismo de la anécdota, no puede sino refrendar -incidiendo el margen que separa a la filosofía de su afuera- "la pertenencia de la filosofía a la exterioridad [...], la insistencia de la dóxa en la filosofía" (1996, p. 45). Si, por una parte, la reducción de la alteridad se acusa como gesto ontológico fundamental, por otra parte, el hecho de que la filosofía no pueda prescindir simplemente de su otro -en este caso, de una anécdota que porta la opinión que la filosofía tiene acerca de su propio vínculo con la verdad-, la arriesga a sacar de quicio a la estructura oposicional que la constituye. De ahí que, contra la auto-representación que la filosofía (en su matriz dialéctica) hace de sí misma, sea posible rastrear, en la historia de la filosofía, la existencia de filosofías que -desbaratando la jerarquía de aquella oposición topológica- han socavado el gozne que regula el paso entre su adentro y su afuera (aquí, entre el lugar consagrado de la verdad como "saber de lo esencial" y la dimensión espuria de la banalidad del mundo que consigna lo anecdótico). Entre estas filosofías que, desestabilizando una cierta imagen del pensamiento, han tomado entre sus manos esta potencia a-tópica de la anécdota, una proximidad particularmente sensible se acusa entre Nietzsche y Diógenes el Perro: "Siempre busca la filosofía hallar la manera de administrar lo exterior [...] Pero también es prueba de que no se trata de lo simplemente ajeno la existencia de filosofías ( $\tan$ diversas, tan dispersas, se diría) que echan mano de tal exterioridad para desplegar una crítica -que no podríamos situar sin más adentro o afuera- de la filosofía como tal, un desmontaje de lo Mismo (que es el riesgo). Y esta crítica, este desmontaje son, pienso, primarios intereses que están inscritos en la estrategia del cinismo antiguo, en el anecdotario de Diógenes el Perro, sobre todo, y también en una embrollada posteridad, mucho más oculta que visible, donde cabría dejar anotados nombres numerosos y varios, emparentados por el estilo y por el tono: Nietzsche es uno de esos nombres, rutilante" (Oyarzún, 1996, p. 45). 
En la moral propia de la lógica trascendente, el saber se verifica en una esfera desconectada de la vida; cuando los espíritus hablan, ven, caminan, viven en compañía, en pocas palabras, cuando existen, no hay conocimiento propiamente hablando [...] Sólo existiendo lo menos posible, un espíritu tiene la oportunidad de volverse semejante al origen primario. Por esto, se precisa la vuelta cotidiana del heroísmo antes anunciado [la autora se refiere al heroísmo de la incertidumbre que atraviesa el pensamiento nietzscheano]: una vez más, parece que la afirmación de la existencia es estrictamente indisociable de la pluralidad (2004, pp. 36-37).

De ahí que podamos vislumbrar, tras la aspiración teórica del filósofo (plasmada en el trazado de la oposición entre el "saber de la verdad" y el "saber de los pozos"), la obsesión correctiva de un conocimiento que aspira a dominar el exceso de la vida. Y dado que la identificación entre el pensamiento y la seriedad se concierta con la negación de todo aquello que nos entre-tiene en la existencia (y, ciertamente, las anécdotas nos entre-tienen en la existencia), resulta sugerente que, en el diálogo platónico, la risa de la joven tracia devenga aciaga ante la conexión establecida por Platón entre la caída en el pozo de Mileto y el final de Sócrates en Atenas. Pues, ciertamente, "en el contexto platónico -como lo subraya Blumenberg en La risa de la muchacha tracia- el punto de referencia de esta historia no es Tales, sino Sócrates" (2000, p. 22). El hecho de que la anécdota proceda de la boca de un Sócrates ya muerto (es Euclides quien recupera el diálogo sostenido entre Sócrates, Teodoro y Teeteto), trae a la memoria el hecho de que "lo que se había anunciado en la risa de la criada había acabado en odio" (Ibíd.). Vista desde la perspectiva de Platón, la risa de la esclava prefigura la sentencia de muerte de Sócrates:

Para hacer que de la boca de Sócrates se hable premonitoriamente del destino de Sócrates ha de haberse tratado ya, con mucha anterioridad a la copa de la cicuta, del martyrium de la idealidad pura. La sangre del testigo de la verdad no se derrama con ello; le sube a la cara, sonrojándole, cuando ante el Tribunal o en otra parte cualquiera tiene que hablar precisamente de cosas que quedan inmediatamente ante sus pies, ante sus ojos. No sólo cosecha risas entre mujeres tracias, sino también entre el resto entero de la plebe (Blumenberg, 2000, p. 30).

La seriedad se expande así sobre la escena de surgimiento de la filosofía. La risa de esta prototípica enemiga de la teoría debe ser corregida ante la 
vista de aquel sacrificio ofrecido a la verdad misma ${ }^{17}$. Pero, como hemos notado, es de este martyrium de la idealidad pura que el filósofo-bufo se ríe. Contra esta lógica sacrificial (que Nietzsche intuye cuán operante está en las obsesiones que atraviesan su propio presente), y contrariando este papel de mártir del filósofo, este "holocausto por la verdad", él declara: "Después de tan jovial preámbulo no quisiera dejar de ser oída una palabra seria: se dirige a los más serios. ¡Tened cuidado, vosotros los filósofos y amigos del conocimiento, y guardaos del martirio! ¡De sufrir 'por la verdad’! ¡Incluso de defenderos a vosotros mismos!" (Nietzsche, 1994a, p. 48). No resulta difícil, ante este gesto, imaginarse a Nietzsche regocijado en la estela del eco de la risa de la muchacha tracia, encontrando en el formidable trazado de la anécdota un recurso punzante para descoser el hilván del tejido que urde la "voluntad de verdad"; no obstante sabemos por Blumenberg que él, que pensó en la risa y en la anécdota como potencias desestabilizadoras del discurso de la verdad y de la voluntad que lo constituye, "con ocasión de la caída en el pozo de Mileto [...] no dice ni una palabra" (Blumenberg, 2000, p. 175). Si hemos supuesto una afinidad entre Nietzsche y la sirvienta tracia, ésta radica simplemente en que ambos se disponen fuera del culto de la verdad. Quisiéramos hacer oír en la risa de la muchacha, risa que no por nada pretendió silenciar el platonismo, la inocente extrañeza de que algo así como la "voluntad de verdad" exista.

Me detengo ahora, para terminar, en esa anécdota sobre la excéntrica fisonomía de Sócrates que encontramos entre las manos de Nietzsche al comenzar nuestro ensayo. Si, como recuerda Deleuze, Nietzsche piensa que "la anécdota es en la vida lo que el aforismo en el pensamiento: algo que interpretar" (2002, p. 156), habría que cartografiar en ella la genealogía de las fuerzas que operan en sordina en el cuerpo del filósofo. Ciertamente, una lectura detenida de esta anécdota de Sócrates es una tarea que debe aquí quedar pendiente, dada la máxima complejidad que puede hallarse en esta doble remisión del incidente en El crepúsculo de los ídolos, y que muestra,

\footnotetext{
${ }^{17}$ Comentando el relato de Diógenes Laercio sobre las posibles muertes de Diógenes, Oyarzún escribe: "Una sola muerte es la de Sócrates, y es decisivo que sea una sola: muerte única. Platón lo supo quizás mejor que nadie, porque supo esto: que sólo sobre esa única muerte era posible fundar la filosofía. La filosofía es impensable sin una relación a la muerte, y la filosofía dominante, imposible sin esta peculiar relación a una única muerte: es el vínculo mismo de la verdad lo que se decide con esto. Puede uno imaginarse que la última provocación diogeniana, en cierto modo la decisiva provocación cínica dispara en contra de esa filosofía dominante y altisonante y sublime, tendría que concernir a la sublimidad de la muerte como fundamento de la filosofía" (Oyarzún, 1996, p. 401).
}

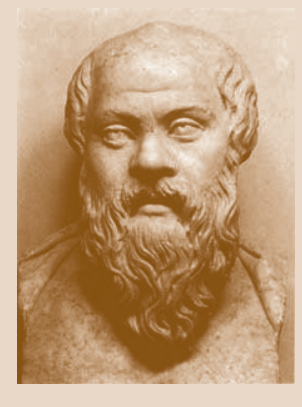

Sócrates 
ante todo, el carácter doble, irónicamente plegado, que la figura de Sócrates tiene para Nietzsche (baste recordar, como indicio, las dos variaciones de la anécdota: entre un Sócrates que se limita a responder al fisonomista: “ $¡ U s-$ ted me conoce, señor mío!" y otro que moraliza y se declara dueño de sí). No obstante, podamos advertir que Nietzsche, rumiando la anécdota, hace visible el cuerpo del filósofo, cuerpo que en la tradición filosófica ha querido ser obliterado (como la anécdota y la risa), pero que la ciencia jovial afirma como condición ineluctable del ejercicio del pensamiento:

Continúa siendo una tarea completamente nueva, que precisamente ahora comienza a alborear ante los ojos del hombre y es apenas perceptible con nitidez: hacerse cuerpo con el saber y hacerlo instintivo -iuna tarea que será vista solamente por aquellos que han entendido que hasta ahora sólo nuestros errores se habían hecho cuerpo, y que toda nuestra claridad sobre nosotros mismos se remite a errores (Nietzsche, 1999, p. 36).

\section{REFERENCIAS}

Birnbaum, A. (2004). Nietzsche. Las aventuras del heroísmo. México: Fondo de Cultura Económica.

Blumenberg, H. (2000). La risa de la muchacha tracia. Una protohistoria de la teoría. Valencia: Pre-Textos.

Cicerón (2005). Disputaciones Tusculanas. Trad. de Alberto Medina González. Madrid: Gredos.

Deleuze, G. (2000). Nietzsche. Madrid: Arena Libros. (2002). Nietzsche y la filosofía. Barcelona: Anagrama.

Derrida, J. (2001). La tarjeta postal. De Sócrates a Freud y más allá. México: Siglo XXI.

Diógenes Laercio (2007). Vidas y opiniones de los filósofos ilustres. Trad. de Carlos García Gual. Madrid: Alianza.

Epicuro (2012). Obras completas. Trad. de José Vara. Madrid: Cátedra.

Foucault, M. (2000). "Nietzsche, la généalogie, l'histoire”. En Lectures de Nietzsche. Paris: Libraire Générale Française.

Nancy, J.-L. (2000). Corpus. Paris: Editions Métailié.

Nietzsche, F. (1994a). Más allá del bien y del mal. Trad. Andrés Sánchez Pascual. Madrid: Alianza.

(1994b). El crepúsculo de los ídolos. Trad. Andrés Sánchez Pascual. Madrid: Alianza.

(1999). La ciencia jovial, Trad. José Jara. Caracas: Monte Ávila.

(2006). La genealogía de la moral. Trad. Andrés Sánchez Pascual. Madrid: Alianza. 
(2007). Humano, demasiado humano. Un libro para espíritus libres. Trad. de Alfredo Brotons. Madrid: Akal.

Oyarzún, P. (1996). El dedo de Diógenes. La anécdota en filosofía. Santiago: Dolmen.

Platón (1988a). “Fedón”. En Diálogos III. Madrid: Gredos. (1988b). “Teeteto”. En Diálogos V. Madrid: Gredos.

Zúñiga, R. (2003). Nietzsche. Comedia y dislocación. Santiago: Departamento de Teoría de las Artes de la Universidad de Chile. 